\title{
HOW TRANSPARENT ARE COMPANIES LISTED ON THE BUCHAREST STOCK EXCHANGE WHEN DISCLOSE THEM CONSOLIDATED FINANCIAL STATEMENTS?
}

\author{
Adriana Tiron-Tudor ${ }^{1}$ \\ Raluca Valeria Ratiu ${ }^{2}$
}

\begin{abstract}
The main objective of this paper is to examine the level of disclosure regarding the consolidated financial statements in the case of Romanian listed companies. In order to measure this, a multiple index was used that quantifies the level of dislosure a company has achieved. The main conclusion, in accordance with our hypotheses is that the disclosure index is higher in the case of first category of listed entities comparing with the second and third category.
\end{abstract}

Key-Words: consolidated financial statements, IFRS, harmonization, disclosure

JEL: $M 41$

\section{Introduction}

This study investigates the disclosure level of Romanian quoted companies over the years 20062009 concerning the consolidated financial stetements. The sample includes all financial and nonfinancial companies whose securities were listed during this period. Data were collected from their published consolidated financial statements on CNVM site and cross-validated with information available on them website. The year 2006 was chosen as the starting point for our analyses because it marks the beginning of mandatory requirements for Romanian quoted entities to disclose the consolidated financial statements. The period analised marks the pre and post Romania accession to the European Union.

The results reveal that there is a positive association between disclosures the consolidated financial statements and the "categories" of quoted entities, comparable to the conclusions reported by studies conducted on more mature markets. The dislosure level is higher for categories I quoted entities then for the category II, accordingly with the segmentation of the BSE.

This paper provides several contributions to the accounting literature. First it adds to the knowledge of transition economies in general and those of Eastern and Central Europe in particular by considering a market which has not been examined before. To our knowledge, it is also the first study that analizes the consolidated financial statements disclosure for Romanian quoted entities. and the evolution of harmonization process concerning the disclosure of consolidated financial statements, and for each year the degree of material disclosure harmonization.

More fundamentally, this research contributes to the literature on financial reporting by showing that the relationship between financial reporting disclosure and financial market segmentation is comparable to those observed in more favorable environments. It also clearly highlights the influence of segmentation imposed by the market on the association between the importancy given by the quoted entities to disclose accounting data and the entities value.

The paper is structured as follows. Section 2 provides a short overview of the legal framework, Section 3 presents the Romanian institutional setting, in particular the BSE and its regulatory environment. Section 4 present a literature review, Section 5 describes the data and the

\footnotetext{
${ }^{1}$ Babeş-Bolyai University Cluj-Napoca, $1{ }^{\text {st }}$ M. Kogălniceanu Street, adriana.tiron@econ.ubbcluj.ro

${ }^{2}$ Babeş-Bolyai University Cluj-Napoca, $1^{\text {st }}$ M. Kogălniceanu Street, raluca.ratiu@econ.ubbcluj.ro
} 
model used in this research, Section 6 reports the empirical results, and Section 7 summarizes the findings and concludes the paper.

\section{Legal framework}

At european level, for companies whose securities are admitted to trading on a regulated market of any Member State is mandatory to appply the Regulation 1606/2002 of the European Parliament and Council on 19th July concerning the application of the International Accounting Standards (known as "IAS Regulation") when elaborating the consolidated financial statements beginning with 2005 year. The aim of this regulation is to harmonize the financial information presented by quoted entities, so as to ensure a high level of transparency and comparability of the financial statements and, as a result, the efficient and profitable operation of the community capital markets and the establishment of the internal market.

At national level, in Romania, starting with 2006, all the entities were obliged to put into practice the Accounting regulations in compliance with the European Directives, thus setting the grounds to meet the prerequisites when Romania was supposed to be integrated into the European Union. (OPFM no. 907/2005 concerning the approval of the juridical persons applying accounting regulations in conformity with the International Financial Reporting Standards (IFRS), as well as accounting regulations compliant with European Directives.)

Since Romania's 2007 adhesion to the European Economic Community (EEC), IFRSs are mandatory for consolidated accounts for listed companies starting January 1st 2007 (OMFP no. 1221/2006), as well as for financial institutions. An option to choose between the 7th ED and IFRSs is available for non-credit and nonfinancial unlisted entities for their consolidated accounts.

\section{Bucharest Stock Exchange ( BSE)}

In Romania, like in other transition economies, rapid changes have taken place in the last twenty years afther the former communism regime collapse. In the way of accession to the European Union, several economic reforms were undertaken, state-owned companies have been privatized and a financial market created.

As most newly established stock exchanges (Alexander \& Bailey, 2003), the BSE is characterized by: short-term trading based on market-price fluctuations rather than long-term investment considerations, low level of domestic savings, the stock-exchange activity has been dominated by foreign capital, a small number of listed companies, low trading volumes, relatively few disclosure requirements.

Listed companies are subject to restrictions, as well as discipline and specific rules of conduct imposed by the market authorities. Companies listed on the BSE are classified in two categories bound by different disclosure and liquidity requirements:

- Class A: minimum share capital 8 milion Euro, minimum operating period 3 years exception for mergers or split companies, positive earnings in the last 2 years, liquidity requirements, financial management requirements.

- Class B: minimum share capital 2 milion Euro

The two-tier structure of the stock market establishes a difference between the so-called "stars" of the market (the most actively traded and liquid shares) and the rest of the shares traded on the BSE. The purpose of this segmentation was to prioritize the information provided to investors by highlighting the most important shares traded in the market. "Class A" companies are subject to higher disclosure requirements and probably closer scrutiny by investors.

The most stringent category, composed of shares issued by the largest companies, can be compared to several small but more mature European markets. The other segment, by contrast, is essentially composed of securities issued by local firms that generally have no counterpart in the financial markets of Western Europe. Because these segments probably do not exhibit the same level 
of efficiency (Pajuste, A 2002). it is possible to assess the influence of market characteristics on the value relevance of accounting data.

\section{Literature review}

\section{a) Financial market maturity}

Several reasons suggest that the financial markets of European transitional economies should exhibit a lower level of value relevance than those of western countries. Second ( Filip, Raffournier, 2010) despite the emergence of financial markets, the financial systems of Eastern and Central European countries remain bank-oriented, with a small number of banks providing the main part of firm financing. As these banks generally have direct access to company information, the assumption has been made that in such systems the demand for timely and value relevant information is lower than in market-oriented financial systems such as those of the United States or the United Kingdom. Ali and Hwang (2000) report evidence consistent with this hypothesis.

In a more recent paper, Hellström (2006) investigates the value relevance of accounting information of Czech vs. Swedish companies. The results confirm that during the 1994-2001 period, accounting information was less value relevant in the Czech Republic than in Sweden. Nevertheless the value relevance of Czech accounting information increased through time as a result of improvements in the institutional and accounting environment of the country. There is no Romanian research that can be compared to the studies mentioned above with regard to the quality of methodology.

\section{b) Accounting data disclosure level}

Research in disclosure level began around the year of 2000. Later studies focus on cross-listed companies seeking to identify significant differences between US listed (and also filing is US) and non-us listed companies. Findings indicate that the overall level of disclosure is greater for companies with US listings (Glaum and Street, 2003).

Unfortunately there is a total dearth of such studies and evidence in Central and Eastern European countries except for those that have been carried out using an international sample, such as Street and Gray (2002). Fekete et all (2008) develop a study about Hungarian data and contributes to understanding the level of compliance with IFRS disclosure requirements and its determinants. Tiron (2010) develop a study about Romanian data and contributes to understanding the level of disclosure requirements and its determinants in the case of consolidated financial statements.

Cooke (1989) measured the extent of the information disclosed by 90 Swedish companies (disclosure harmonization). The index was composed of 224 items which we considered should be included in the financial statements. Each item is considered a dichotomous variable; we assigned the value one if the information was provided and zero if not. Weightings were not used, so each item had the same importance.

\section{Data collection and the research model}

In the study we started to list the companies submitted to BSE, from which we selected all companies from category I to category II. For these companies we have determined the ones that are part of a group of companies. The next step we further limited our analysis to companies that have mandatory preparation and submission of consolidated financial statements.

From the total of 21 entities listed in the Category I, 7 were excluded from our sample because for them was not mandatory to elaborate consolidated financial statement.

Of the 47 companies listed in Category II of the Bucharest Stock Exchange, 22 are part of a group of companies operating in non-financial sector. Of these 22 companies, only 12 are parent who need to prepare and submit consolidated financial statements according to the criteria listed above. These 12 companies were used in our study. 
The structure of our sample is the follow:

Sample description

Number of entities $(2006,2007,2008,2009)$

Romanian listed companies :

- Banks -

- Investment funds -

- Entities in non-financial sector

Table no. 1

Were eliminated from our study the company listed in category III and the unlisted category because there weren't entities that must prepare and submit consolidated financial statements.

To asses the level of harmonization we used a reference index as described by Cooke in 1989, this is useful because we can show with only one number the level or harmonization (Ahmed and Courtis, 1999, Coy and Dixon, 2004).

A major problem was to establish which issues should form the index, in other words we searched for those points which in our opinion should be included in the consolidated financial statements (Tiron-Tudor, 2010).

The index was composed of elements of the entire set of consolidated financial statements and was complemented with an item on the audit report. In the subchapter "Components of financial statements" we show the six selected elements thus making the maximum score to be 6 . Reporting Index $(\mathrm{RI})=\Sigma \mathrm{i}=1, \ldots, \mathrm{n}$ where $\mathrm{X}=1$ if $\mathrm{Xi} \mathrm{Xi}$ index is reported, and 0 if the index is not reported. A score based on a set of six indexes for 2006-2009 was calculated for each group analyzed. This index will allow us to show that the group reported consolidated financial information in accordance with IAS / IFRS and also allows us to verify that the group reported a greater amount of information (Tiron-Tudor, 2010).

Data that were used in this study are from the annual reports. Using annual reports obviously has great advantages but also some shortcomings. Data collection is laborious, sometimes companies do not send their financial information and such reports may not be available in a language the researcher can understand (Tiron-Tudor, 2010).

Companies that are listed on the stock exchange are required to prepare annual and semiannual consolidated financial statements. We analyzed the existence of six consolidated reports, prepared in accordance with IFRS for each group of companies listed on the Bucharest Stock Exchange.

Analysis was done at the quantitative level and watched whether or not the company has filed consolidated financial statements and also at the quality level we followed each of the six elements listed above and note if it has been prepared by the reporting companies.

\section{Results of the empirical study}

For the period 2006-2009 there were 14 Romanian entities, from the first BVB category and 12 from the second BVB category which should present annual and interim consolidated financial statements. Just a part of them full fill these requirements as we can see in the follow table:

CFS cantitative disclosure index for our sample

\begin{tabular}{|l|l|l|l|l|}
\hline ELEMENT & $\mathbf{2 0 0 6}$ & $\mathbf{2 0 0 7}$ & $\mathbf{2 0 0 8}$ & $\mathbf{2 0 0 9}$ \\
\hline TOTAL CAT I & 14 & 14 & 14 & 14 \\
\hline TOTAL CAT I SFC & 5 & 9 & 13 & 13 \\
\hline CAT 1 \% & $36 \%$ & $64 \%$ & $93 \%$ & $93 \%$ \\
\hline TOTAL CAT II & 12 & 12 & 12 & 12 \\
\hline TOTAL CAT II SFC & 3 & 6 & 7 & 4 \\
\hline CAT 2 \% & $25 \%$ & $50 \%$ & $58 \%$ & 33 \\
\hline TOTAL \% & $31 \%$ & $58 \%$ & $77 \%$ & $62 \%$ \\
\hline
\end{tabular}

Table no. 2 
About the annual CFS there is positive evolution, for the period 2006-2008 for both categories, from $31 \%$ to $77 \%$. In 2006 the number of CFS is limited at 5 and 3 but in 2008 the number increase at 13 , respectively 7 , so only one entity from the first category not presents CFS. Comparing the categories, the first category entities are more serious concerning the disclosure of consolidate financial statements which is not the same analising the second category.

The set of CFS and the audit report for CFS were analyzed, and the calitative disclosure indexes of CFS for our sample were presented in the follow table:

Table no. 3

CFS calitative disclosure indexs for our sample

\begin{tabular}{|l|r|r|r|r|}
\hline ELEMENT & $\mathbf{2 0 0 6}$ & $\mathbf{2 0 0 7}$ & $\mathbf{2 0 0 8}$ & $\mathbf{2 0 0 9}$ \\
\hline TOTAL CAT I SFC & 5 & 9 & 13 & 13 \\
\hline SFC complet & 5 & 7 & 9 & 10 \\
\hline SFC incomplet & 0 & 2 & 4 & 3 \\
\hline TOTAT CAT II SFC & 3 & 6 & 7 & 4 \\
\hline SFC complet & 2 & 5 & 5 & 4 \\
\hline SFC incomplet & 1 & 1 & 2 & 0 \\
TOTAL I + II & 8 & 15 & 20 & 17 \\
SFC complet & 7 & 12 & 14 & 14 \\
SFC incomplet & 1 & 3 & 6 & 3 \\
\hline
\end{tabular}

For category I entities, in 2006 the 5 sets of annual CFS were complete, with all elements of CFS and also the audit report for them. In 2007 the number of CFS increase at 9 but the content is less qualitative because there are two entities who present only the consolidated balance sheet, profit and loss account, cash flow statement and own equity movement, without accounting policies and explanatory notes, but joined by the auditor report. In 2008 the evolution is in the same trend like in the previous year, so the number of annual CFS increases at 13 but the quality also decrease, there are 4 CFS which not receive the maximum disclosure index because there are missed parts of the complete set of CFS or are not audited. In 2009 there were 10 "full" CFS for the firs category entities.

For category II entities, in 2006 the 2 sets of annual CFS were complete, in 2007 and 2008 the number of CFS increase at 6 , respectively at 7 but the content is less qualitative because there are two entities who present only the consolidated balance sheet, profit and loss account, cash flow statement and own equity movement, without accounting policies and explanatory notes, and the auditor report. In 2009 the evolution is negative concerning the category II both in cantitative and calitative terms comparing with the total entities included in this category and also with the first category.

\section{Conclusions}

The focus of this paper is to measure the consolidated financial stetements disclosure index of quoted entities in Romania, an emerging market in a transitional economy. Several conclusions can be drawn from its findings.

First, the preparation and disclosure of consolidated financial statements is not a common practice among Romanian firms. In the analised period 2006-2009, the number of entities disclosing consolidated financial statements (even them obligativity) is lower. Mandatory consolidation requirements were introduced explicitly only in 2007 but even after 2007, consolidation requirements were considered by national regulators "not so important" so the effect of this "national point of view" is reflected in the low degree of disclosure.

Second, the strength of the association between accounting data and the category of entity ( I or II). The influence of market segmentation is clearly established. As expected, Category I entities composed by larger companies, more actively traded, and, therefore, more visible to the market, present the higher cantitative and qualitative disclosure degree. 
As most empirical studies, this one is subject to several limitations. First, the sample is small compared to previous studies. This objection (Filip and Raffournier 2010) is common to all studies dealing with emerging economies, especially those of Eastern and Central Europe. Because these markets are recent, the number of listed companies is small and it is not possible to collect data sets as large as those of studies conducted in highly developed countries. Nevertheless, in the particular case of this study, this criticism should be mitigated given that the sample includes all Romanian companies listed on the BSE, banks and insurance companies excepted.

Another limitation relates to market inefficiency. As most emerging markets, the BSE is probably less efficient than more mature stock markets. Prior value-relevance studies are generally silent on whether the market is efficient or not.

There are several directions that future research could take. First, it would be interesting to continue our analysis with data from 2010 and subsequent years. Another valuable exploration would be to continue our qualitative research by analising each component of consolidated financial statements, the compliance with IFRSs.

\section{References}

1. Alexander, D., Bailey, D., 2003. Eastern Europe: Overview. 5th ed. In D. Alexander \& S. Archer (Eds.), European Accounting Guide. (pp. 22.01-22.08)New York: Aspen Publishers.

2. Ali, A., Hwang, L. S., 2000. Country-specific factors related to financial reporting and the value relevance of accounting data. Journal of Accounting Research, 38, 1-21

3. Cooke, T E, 1989 Disclosure in the Corporate Annual Reports of Sweeden Companies,

4. Accounting and Business Research , 19 (74) pp. 113-24

5. Glaum, M., Street, D.L., 2003 Compliance with the Disclosure Requirements of Germany's New Market: IAS Versus US GAAP, Journal of International Financial Management and Accounting, 14(1), pp. 64-100.

6. Fekete $\mathrm{Sz}$ et all, 2008 - Factors Influencing the Extent of Corporate Compliance with IFRS. The Case of Hungarian Listed Companies, ssrn.com

7. Filip A., Raffournier B., 2010 - The value relevance of earnings in a transition economy: The case of Romania, The International Journal of Accounting 45 (2010) 77-103

8. Hellström, K., 2006. The value relevance of financial accounting information in a transition economy: The case of the Czech Republic. The European Accounting Review, 15, 325-349.

9. Mustată, R., 2008 Sisteme de măsurare a armonizării si diversitătii contabile - între necesitate si spontaneitate. Casa Cartii de Stiinta Publishing House, Cluj Napoca.

10. Pajuste, A., 2002. Corporate governance and stock market performance in Central and Eastern Europe: A study of nine countries, 1994-2001. Working paper, Stockholm School of Economics

11. Street, D.L., Gray, S.J., 2002. Factors influencing the extent of corporate compliance with International Accounting Standards: summary of a research monograph, Journal of International Accounting, Auditing and Taxation, 11, pp. 51-76.

12. Tiron Tudor A., 2010. Disclosure practices concerning consolidated financial statements of Romanian groups of entities, Oradea, Annales of Oradea University, Economic Studies series, Tom XIX, July, 2010, pag 601- 605 